\title{
THE INFLUENCE OF ORGANIZATIONAL CULTURE, WORK MOTIVATION, AND ORGANIZATIONAL COMMITMENT TO THE PERFORMANCE OF PRINCIPALS
}

\author{
Puji Syamsuri \\ Education and Culture Departement Samarinda east Borneo \\ pujisyamsuri@gmail.com
}

\begin{abstract}
The purpose of this study was to determine the influence of organizational culture, work motivation, and organizational commitment to the performance of principals of elementary school in Samarinda. The results of the study findings that: (1) Organizational cultures have directly positive effect to the performance of principals, (2) Work motivation have directly positive effect to the performance of principals, (3) Organizational commitment have directly positive effect to the performance of principals, (4) Organizational culture have directly positive effect to the organizational commitment, (5) Work motivation have directly positive effect to the organizational commitment. This research was carried out in the environment of Samarinda Government that involving 60 principals of elementary school in Samarinda as the study samples. The determination of study samples was done by using random sampling. The data collection using instrument with a Likert scale of measurement consist of 5 answer options and the data analysis using path analysis technique. Based on the study, organizational culture, work motivation, and organizational commitment have directly positive effect to the performance of principals. Therefore the variables of the study are recommended to the Government of Samarinda to increase the performance of elementary school in Samarinda.
\end{abstract}

Keywords: Organizational Culture, Work Motivation, Organizational Commitment and Performance of Principals, Education Office of Samarinda City.

The performance of elementary school principal in Samarinda so far less optimal, less developing culture orhanisasi, work motivation and organizational commitment so that the expected performance is still low. This is in line with Robbin's statement of performance is the result of an evaluation of the work performed compared to the predefined criteria (Tiyadi, 2012). Udari Parek in Stiyadi performance or performance is influenced by the ways taken, the effort is done, but in turn the performance of work affects satisfaction and reward. While the factors, ways and efforts, satisfaction and reward have a two-way relationship (UNJ, 2012).

Performance is a picture of the work done someone, or in other words performance is the performance of a person. The performance is related to what task is performed by someone who is responsible (Hamzah Uno, 2012).

Performance is defined as achievement, showing an activity or deed and performing tasks that have been charged, the understanding of performance is often identified with work performance, because there are similarities between performance with work performance and is an initiative to carry out work. Job performance is the result of someone's work in a certain period (Supardi, 2013).

Changes in the attitude of an employee to his performance ability is no other effect of performance evaluation yanag implemented. As Paul J. Jerome has pointed out that performance evaluation is a process that includes planning from the beginning and maintaining it regularly, performance planning takes time and demands thinking (Paul Jeromo, 2001).

Performance assessment Fitzpatrick and Morrison, state that "The performance is a sequence of responses aimed at modying the environment in specified ways". (Robert L. Jhonson, (2009). 
Performance is a sequence of responses aimed at modifying the environment in such a way that the work environment becomes fun, exciting and rewarding employees seriously improve its performance. Performance is the performance that has been achieved in carrying out the task within a certain period to achieve the goals set with indicators of job planning, job quality, quantity of work, cooperation in work, and initiative in work.

Researchers see there are factors that influence the decrease or low performance of the principal of public elementary school in Samarinda, one of which is organizational culture factor, work motivation and organizational commitment.

Empirical data from the results of the performance assessment of the principal of public elementary schools in Samarinda: (1) A is a very good value range 91 to 100 as many as 12 people or $6.5 \%$, (2) B is a good category range 76 to With 90 as many as 91 people or $49 \%$, (3) the value of C is enough category range 61 to 75 as many as 81 people or by $43 \%$ and (4) K value is Less (less than) 60 as much as 2 people or $1,1 \%$. Acquisition of A (Very good) value as performance category Principal expected new mencai $6.5 \%$ or only 12 people from 184 principals. Means the performance of Elementary School Principal in Samarinda City to achieve the value of A still needs to be improved (Diknas Kota Samarinda, 2014).

While the Competency Test results from 94,520 principals published by the archipelago teacher forum describe the following data: (1) the average score based on the principal who already has a Unique Number of School Principals (NUKS) 50.20 while the headmaster who has not Have NUKS 44,32, (2) the mean value per dimension yields: leadership 42,83, school development effort 46,12, supervision 35,52, managerial 47,11 and entrepreneurship 46,98, (3) (4) the average value based on years of service yields a value of: ( 1 to 4 years 4516 , ( 5 up to 4 years 4516,8 years 44.03 ), (9 to 12 years) 41.09, (above 12 years old 40.93), (5) the mean score by age yields a score of: (age $<46$ years $=46.30)$, (Age 46 to 50 years $=45.08)$, (age 51 to 55 years $=41.05)$ and (age over 55 years =37.31), (6) average grade per level of production The school principal level is 51,91, principal of junior high school level 49,86 and principal of elementary level 42,60 (Blog, spot, 20015).

Wibowo also said that creating a high-performance organization requires building a strong and compact culture of support in every effort required to produce extraordinary ones (Wibowo, 2001).

Organizational culture is the principal's perception of the values and beliefs of the organization and it is made a standard rule for employees to be implemented in achieving organizational goals. With an honest and high integrity indicator, has a noble ethical ethic and provides rules, rules and rules that apply, responsible and accountable, respect the rights and do not blame others, love the job and willing to work hard, improve transparency and coordination, high discipline, And understated in life.

The second factor, which affects the performance of principals is the motivation of work. In carrying out the task of a principal is expected to create a healthy work climate, and can increase high work productivity and can increase production, so to create a healthy and productive work climate requires motivation, as Muchdarsyah said that a healthy work climate can To encourage openness attitude both from employee and employer side so that able to grow work motivation which is unidirectional between employee and entrepreneur in order to create job serenity and business continuity towards increasing production and work productivity (Muhdarsyah, 2001).

Schein (1992) defines the culture of a group or organization as a shared assumption and belief about the world and their place in it, the nature of time and space, human nature and human relations (Gary Yulk, 2005).

Organizational culture is a system of disseminating beliefs and values developed within an organization as a guideline of the behavior of its members (Shemercom, Hurn and Osborn (Victoria Misroshnik, 2013). Work motivation is a series of encouragement drives originating both within and 
outside of an individual, to initiate work-related behavior, and to determine the form, direction, intensity, and duration of the work motivation itself (Pinder, 2008).

Matteson and Ivancevich (1989: 192) work motivation is the need, encouragement, and stimulus that can spur employees behave so willing to work UNJ, 2012). Robbin and Judge (2007) define motivation as a process that explains intensity, direction and perseverance to achieve a goal. Samsudin (2005) provides a sense of motivation as a process of influencing or encouraging from the outside of a person or working group so that they want to implement something that has been established. Motivation can also be interpreted as a driving force intended as a natural urge to satisfy and sustain life. Mangkunegara (2005: 61) states the motivation is formed from the attitude (abtitude) employees in the face of work situations in the company. Motivation is a condition or energy that moves the employee self directed or directed to achieve corporate organization goals. The mental attitude of employees who are pro and positive to the work situation that strengthens the motivation to work to achieve maximum performance (online theory wordpress, 2015)Motivation plays an important role and gives enough impact phenomenon in performance improvement, because it can explain why someone is willing to do the job. The need for work motivation to produce good work is also conveyed by Pandji Anogara that motivation of work is something that raises the spirit or the drive of work. Therefore, the work motivation in the psychology of the work is usually called the driving spirit of work. Strong and weak motivation of work of a worker participate mentukan big small achievement.

Robbin in Franciscus, organizational commitment is a condition when a member sides with the organization with its goals, and intends to maintain membership within the organization. Ivancevich, Donnely and Gibson declare someone with a strong commitment will survive despite pressing work, and if necessary provide themselves with long hours for faithfulness to organizational goals (UNJ, 2012).

The result of path coefficient calculation in this research are: (1) there is direct influence of organizational culture $(\mathrm{X} 1)$ on principal performance $(\mathrm{Y}) \mathrm{py}_{1}=0,39, \mathrm{t}$ value $=3,78$; Value $\mathrm{t}$ table at significance level $\alpha=0.01=2.66$ for $\mathrm{dk}=56$, because the value of $\mathrm{t}$ arithmetic $>\mathrm{t}$ table then Ho is rejected and $\mathrm{H} 1$ accepted. Thus it can be concluded that organizational culture has a direct positive effect on the performance of principals; (2) there is a positive direct effect of work motivation (X2) on the performance of principal (Y). The result of path coefficient calculation got py $2=0,38$ value tcount $=3,72$, thable value at significance level $\alpha=0,05=2,66$ for $\mathrm{dk}=56$, because $\mathrm{t}$ count value $>\mathrm{t}$ table then $\mathrm{Ho}$ is rejected and $\mathrm{H} 1$ accepted. Thus it can be concluded that work motivation has a direct positive effect on the performance of the principal; (3) there is a direct positive influence of organizational commitment (X3) on principal performance $(\mathrm{Y})$, the result of path coefficient calculation obtained py $3=0,25$, tcount $=2.05$, ttable value at significance level $\alpha=0,05=2,00$ for $\mathrm{dk}=56$, because the value of $\mathrm{t}$ arithmetic $>\mathrm{t}$ table then Ho is rejected and $\mathrm{H} 1$ accepted. Thus it can be concluded that organizational commitment have a direct positive effect on the performance of principals; (4) there is a positive direct effect of organizational culture (X2) on organizational commitment (X3). From the calculation of path coefficient obtained p31 $=0,52$, tcount $=6,23$, ttable value at significance level $\alpha=0,01=2,66$ for $\mathrm{dk}=57$, because tcount $>$ ttable then Ho is rejected and $\mathrm{H} 1$ accepted. Thus it can be concluded that organizational culture has a direct positive effect on the performance of principals; (5) there is a positive direct effect of work motivation (X3) on organizational commitment (X3). The result of path coefficient calculation obtained p32 $=0,49$, tcount $=2,66, \mathrm{t}$ value table at significance level $\alpha=0,01=2,66$ for $\mathrm{dk}=57$, because tcount $>$ ttable then $\mathrm{Ho}$ is rejected and $\mathrm{H} 1$ accepted. Thus it can be concluded that the motivation of work directly positive effect on organizational commitment. The main purpose of this study is to know and obtain a clear picture whether or not: (1) Direct positive influence of organizational culture on the performance of principals. (2) Positive positive influence of work motivation on principal performance. (3) Direct positive influence of organizational commitment to the performance of 
principals. (4) Direct positive influence of organizational culture on organizational commitment. (5) Positive positive influence of work motivation on organizational commitment.

\section{METHOD}

This research uses quantitative approach, research method used is survey with causal approach. Survey result is analyzed using multivariate statistic with path analysis technique. The study population was 184 principals of public primary schools. The sample of respondents based on random sampling with slovin formula amounted to 60 principals of public elementary school in Samarinda. The unit of analysis in this study was the head of public elementary school in Samarinda. The data collection in this research is done through distributing questionnaires designed in the form of Likert scale. On this scale the proposed statements are supplemented with five alternative answers and their weightings for each alternative. For the Linkert scale, the details are: Always $=5$, Often $=$ 4, Sometimes $=3$, Rarely $=2$ and Never $=1$.

This study uses four research instruments to measure principals' performance, organizational culture, work motivation and organizational commitment. The instrument is tested to 30 respondents, so that the obtained items are valid (appropriate) and reliable (level of trust). Prior to the path analysis, conducted some testing requirements that must be met are: data normality test, linearity test, and test of regression significance.

\section{RESULT}

Description of research variables consisting of organizational culture, work motivation and organizational commitment to principal performance are presented in descriptive statistics which include minimum score, maximum score, range, mean, mode, median, standard deviation and Variance. Testing requirements analysis used in this study include the normality test, linearity test and regression significance test. Normality testing in this study using estimation data. By using the Liliefors test, then the data is declared normal if Lhitung $<\mathrm{L}$ table, whereas data otherwise not normal if Lhitung> Ltabel. Here is a summary of the normality test results for each error estimate.

Table 1. Est. Est. EstWith Liliefors Test (Lo)

\begin{tabular}{||l|c|c|c|c|c||}
\hline Variation & $\mathbf{N}$ & $\mathbf{A}$ & $\mathbf{L}_{\mathbf{0}}$ & $\mathbf{L}_{\text {table }}$ & Conclusion \\
\hline${\mathrm{Y} \mathrm{On} \mathrm{X}_{1}}$ & 60 & 0,05 & 0.105 & 0,114 & Normal \\
\hline${\mathrm{Y} \text { On } \mathrm{X}_{2}}$ & 60 & 0,05 & 0.066 & 0,114 & Normal \\
\hline${\mathrm{Y} \text { On } \mathrm{X}_{3}}$ & 60 & 0,05 & 0.051 & 0,114 & Normal \\
\hline $\mathrm{X}_{3}$ On $\mathrm{X}_{1}$ & 60 & 0,05 & 0.021 & 0,114 & Normal \\
\hline $\mathrm{X}_{3}$ On $\mathrm{X}_{2}$ & 60 & 0,05 & 0.040 & 0,114 & Normal \\
\hline
\end{tabular}

Meanwhile, for testing the significance of regression using Analysis of Variance (ANAVA). If the value of Fcount> Ftable at the error rate $(\alpha) 0.05$, then the regression equation is significant, and at the error rate $(\alpha) 0.01$, then the equation is very significant.

The result of regression significance test for each influence of organizational culture, work motivation and organizational commitment to principals performance is summarized in table 2 .

Table 2. Summary of Regression Linearity Test Results

\begin{tabular}{|l|c|c|c|c|c|}
\hline Variable & $\mathbf{N}$ & $\boldsymbol{\alpha}$ & $\mathbf{F}_{\text {count }}$ & $\mathbf{F}_{\text {table }}$ & Conclusion \\
\hline $\mathrm{Y}-\mathrm{X}_{1}$ & 60 & 0,01 & 1,07 & 1,85 & Linier \\
\hline $\mathrm{Y}-\mathrm{X}_{2}$ & 60 & 0,01 & 1,18 & 1,84 & Linier \\
\hline $\mathrm{Y}-\mathrm{X}_{3}$ & 60 & 0,01 & 2,31 & 2,21 & Linier \\
\hline $\mathrm{X}_{3}-\mathrm{X}_{1}$ & 60 & 0,01 & 1,27 & 1,85 & Linier \\
\hline $\mathrm{X}_{3}-\mathrm{X}_{2}$ & 60 & 0,01 & 0,73 & 1,86 & Linier \\
\hline
\end{tabular}


Hypothesis testing of research done after test requirements regression analysis has been fulfilled. Regression is performed to test the relationship between variables, among them must meet the requirement that the variables have a linear relationship, in addition to test the linearity between research variables and to find out how much influence the independent variables X1, X2 and X3 to the dependent variable $\mathrm{Y}$.

To know the influence between research variables used statistical analysis techniques Product Moment correlation and path coefficient shown in the final model of the path diagram. The amount of free variable contribution $(\mathrm{X})$ to dependent variable $(\mathrm{Y})$ used multiple regression analysis technique and path analysis with the help of computer program SPSS for windows version 17.0. To test the research hypothesis is done by calculating the coefficient of the path. Based on the proposed hypothesis there are four path coefficients tested $t$, which is stated means if thitung $>$ ttable, otherwise it can be considered the path is meaningless.

Overall after dialed path analysis, with two models namely; (Y), (2) Working Motivation (X2) on Principal Performance (Y), (3) Organizational Commitment (X3) on Principal Performance (Y), ( 4) Organizational development (X1), to Organizational Commitment (X3), (5) Work Motivation (X2) to Organizational Commitment (X3). After the calculation with SPSS for windows version 17.0 then, obtained the summary of path coefficient and regression as in the model picture as follows:

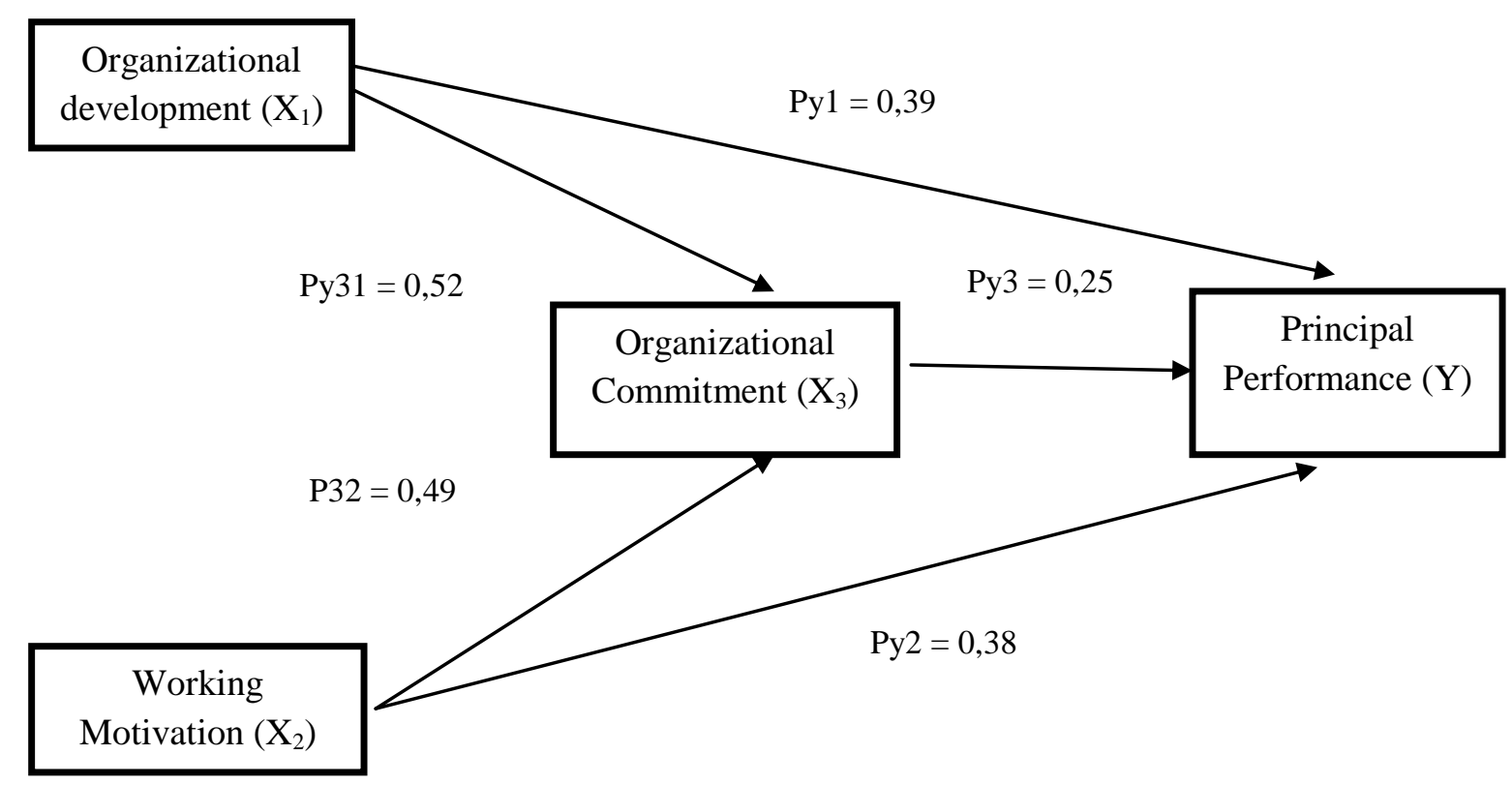

\section{Figure 1. Path Coefficient and $t$ arithmetic Organizational Culture, Work Motivation and Organizational Commitment to the Performance of Elementary School Principal in Samarinda City}

The results show that the theoretical model tested has corresponding to the structure of the equation based on emperical data. Thus the results obtained from this study in accordance with existing theories.

\section{DISCUSSION}

From the results of the first hypothesis testing has been done, it was concluded that organizational culture has a direct positive and significant effect on performance. These findings provide empirical evidence that a strong and well-executed organizational culture will improve the performance of the principal. This habit can then form an organizational culture. Behavior work that 
becomes habituation will be able to form behavior of good attitude attitude, values, and beliefs held by a group of people from generation to generation in the form of performance of principal. A set of attitudes, values, beliefs and behaviors held by an individual or group of people who are communicated appropriately and appropriately will be able to improve their essential skills, role and duties that ultimately performance will increase. Thus it can be concluded that organizational culture has a direct positive effect on the performance of principals. Testing the second hypothesis proves that the motivation of work have a direct positive and significant effect on the performance of principals. Principal performance is something that raises the spirit or the drive of work. Principal Performance as a morale booster. Strong and weak Performance Principal of a workforce to determine the achievements. Principal Performance is an effort that can generate, direct, and Maintaining individual behavior according to work environment. The performance of the principal is influenced by internal and external factors and motivation is the desire within a person that causes the person to take action to achieve the goal, which measures the responsibilities of the employee, as a basis for school improvement and development. These findings illustrate that empirically that the work motivation carried out by the principal will improve the performance of the principal. This fact shows that the work motivation must be done by the principal in order to carry out his duties for improvement and improvement of performance towards the goal of the school. Thus it can be concluded that the motivation of work have a direct positive effect on the performance of principals. The third hypothesis testing proves that organizational commitment has a positive and significant impact on principal performance. A school principal who has alignment to his or her institution, is a reflection in the implementation of a personal commitment. The principal's commitment is that high employment involvement means taking sides in a particular individual's individual job, which is high in favor of the organization that recruits the individual. In school organizations the citizens of the school are professionals in performing their duties, as their performance. These findings illustrate that empirically that high organizational commitment will improve the performance of principals. Testing the fourth hypothesis, proving that organizational culture has a positive and significant impact on organizational commitment. Organizational culture shows the system of collective agreements held by members of the organization, collective agreements constitute a set of essential characteristics of organizational values. The set of organizational values becomes a commitment in the work environment, in shaping the type of attachment within the work environment. A pleasant working atmosphere and well-maintained communication, or assigned tasks make employees passionate and enthusiastic so that they enjoy their work at the institution, is a step towards improving organizational commitment. Thus it can be concluded that organizational culture has a direct positive effect on organizational commitment. Testing the fifth hypothesis, proves that the motivation of work has a positive and significant impact on organizational commitment. Motivation is a driving force that results in a person or organization member willing and willing to mobilize abilities in the form of skills or skills, manpower and time to organize various activities that are his responsibility. Encouragement of employees to work hard to work hard, because basically the organization not only expect capable, capable and skilled employees, as a form of commitment. Organizational commitment is indispensable and always attached to an individual employee including a principal. Commitment is as a sense of identification, trust in organizational values, willingness to do their best for the benefit of the organization and loyalty of the desire to remain a member of the organization concerned. In general, research related to employees with strong affective commitment will stay with the organization because they want to stay. Employees who have strong continuous commitment because they have to stay with the organization. And employees who have a strong normative commitment because they feel they have to stay. Encouragement that arises both from within itself and external factors, which can provide a significant driving force for the creation of the passionate performance of a school principal to effectively and integrated with all the efforts it has. This condition leads to an alignment, as an incentive to increase organizational 
commitment. These findings illustrate that empirically work motivation enhances organizational commitment.

\section{CONCLUSION}

The results of this study reinforce the theory that organizational culture, work motivation and organizational commitment lead to improved principals' performance. The efforts undertaken are: (1) Organizational culture needed efforts quickly and accurately to improve the performance that is; (a). Socialize organizational culture more deeply from superiors and subordinates that organizational culture is important; (b) create a harmonious relationship between superiors with employees and society, (c) facilitate the existence of an ideal management system for employees so that employees feel fair, transparent and consistent feelings by management in running the organization, (d) Have ethics, noble character (e) Loving work and willing to work hard, never give up, work hard and be happy in working (f) Providing modest cotoh in the life and livelihood of employees, not arrogance and low self-esteem. Organizational culture needs to be developed and exemplified in every school as a culture that is executed in carrying out daily tasks and responsibilities in achieving good principal's performance; (2) the performance of principals can be improved through improvement of work motivation. Efforts undertaken to improve work motivation are: Perform regular and continuous school meetings with all school residents. The meeting begins with a spiritual splash (1015 minutes), for spiritual refreshment, in order to carry out daily tasks with the utilization of information technology. Coaching individuals and groups, for teachers and principals with other problems they face. Headmaster with care, from the heart of heart to find the best solution, so that personal or group problem in the job, through network technology available. Provide clear rewards and punishments to all school members in performing their duties, in accordance with their respective performance. Can undertake activities such as: (a) Include all school residents, parent / guardians in a professional manner, not just in school funding. This can be done through the preparation, implementation, and evaluation of school activities, according to their expertise. School principals' performance can be seen from accountability reports to all parents transparently, accountable at least twice a year. (b) The principal facilitates parent forums, in order to carry out activities well, where discussion can be used or to accommodate input from the community, so as to improve the quality of the school.

\section{REFERENCES}

Anogara, Pandji. (1002) Psikologi Kerja. Jakarta, Rineka Cipta.

Atmodiwirio,Soebagio. (2001). Manajemen Pendidikan Indonesia. Jakarta: $\quad$ Ardadizya Jaya.

Craig C. Pinder. (2008). Work Motivation In Organizational Behavior, Second Edition. USA: Library of Congres Cataloging In Publication Data.

Fransiscus. (2002). Jurnal Manajemen Pendidikan. Jakarta: UNJ, Prodi Manajemen Pendidikan.

Gary Yukl. (2005). Leadership in Organization (Kepemimpinan Dalam Organisasi), Alih Bahasa Budi Supriyanto. Jakarta: Indeks.

Hasil kinerja Kepala Sekolah Dasar Negeri Kota Samarinda Tahun 2014, Dinas Pendidikan Kota Samarinda 2014.

Hasil UKKS dan UKPS Online tahun 2015, Forum Guru Indonesia, forumgurunusantara.blogspot.co.id

James L Gibson, John M Invancevich, dan Jame H. Jr Donnelly. (1997). Manajeman, Alih bahasa Zuhad Ichyaudin. Jakarta: Erlangga.

Jerome,Paul J. (2001). Mengevaluasi Kinerja Karyawan. Jakarta: PPM.

Kusnadi. (2002). Masalah, Kerja Sama, Konflik dan Kinerja (Konteporer \& Islam). Malang: Taroda.

Miroshnik,Victoria. (2013). Organizational Culture and Commitment, Tranmission in Multinational. United States: Plagrave Macmiullan.

Robbins, Stephen. (2007). Perilaku Organisasi Organization Behavior, Edisi 12, Buku 1. Jakarta: Salemba Empat. 
Robiin, Stepphen P. (1994). Teori Organisasi Struktur, Desain dan Alplikasi, alih bahasa Jusuf Udaya, Edis 3. Jakarta: Arcan.

Siagian, Sondang P. (1998). Manajemen Sumber Daya Manusia. Jakarta: Bumi Aksara.

Sinungan, Muchdarsyah. (2000). Produktivitas apa dan bagimana. Jakarta: Bumi Aksara.

Supardi. (2013). Kinerja Guru. Jakarta: P Raja Grafindo.

Suparno, Eko Widodo. (2015). Manajemaen Pengembangan Sumber Daya Manusia. Yogyakarta: Pustaka Pelajar.

Tilaar. (2001). Beberapa Agenda Reformasi Pendidikan Nasioanal dalam Perspektif $\quad$ Abad 21. Magelang: Indonesia Tera.

Uno, Hamzah B. dan Lamatenggo, Nina. (2012). Teori Kinerja dan Pengukurannya. PT Bumi Aksara.

Wibowo. (2001). Budaya Organisasi sebuah kebutuhan untuk meningkatkan kinerja jangka panjang. Jakarta: Rajagrafindo. 